\title{
Glutamine synthetase partitioning in native and introduced salt marsh grasses
}

\author{
Eric L. G. Hazelton ${ }^{1,2, *}$, Thomas J. Knight ${ }^{1}$, Theresa A. Theodose ${ }^{1}$ \\ ${ }^{1}$ Department of Biological Sciences, University of Southern Maine, Portland, Maine 04104-9300, USA \\ ${ }^{2}$ Present address: Graduate Program in Ecology, Department of Watershed Sciences, Utah State University, Logan, Utah, USA
}

\begin{abstract}
Plants with higher glutamine synthetase (GS) activity in photosynthetic tissues than below-ground structures (high leaf:root [L:R] GS activity) show growth advantages over plants with a low L:R GS activity ratio. The benefits of a high L:R GS activity ratio are well documented in agricultural systems, but little is known about the ecology of GS partitioning in natural systems. To determine the ecological significance of GS partitioning, we measured above- and below-ground GS activity in Spartina grasses field-collected from a Maine salt marsh and others raised in a growth chamber from seed. The more stress-tolerant, faster growing $S$. alterniflora had a higher L:R GS activity than $S$. patens in chamber- and marsh-grown plants throughout the growing season. Additionally, we compared GS partitioning in native and introduced subspecies of Phragmites australis. While we did not find a significant difference between the subspecies, the L:R GS activity in both native and introduced reeds was among the highest reported. Our results indicate that high L:R GS activity corresponds with observed stress tolerance, growth and competitive ability in both natural and agricultural systems.
\end{abstract}

KEY WORDS: Nitrogen metabolism · Spartina $\cdot$ Salt marsh · Glutamine synthetase $\cdot$ Phragmites australis $\cdot$ Native Phragmites $\cdot$ Invasive plants $\cdot$ Enzyme partitioning

\section{INTRODUCTION}

In New England salt marshes, the mean high waterline separates 2 species of cordgrass (genus Spartina, Poaceae). Above the mean high water line is a lawn of Spartina patens (Aiton) Muhl.; below is a monoculture of Spartina alterniflora Loisel. (Bertness \& Ellison 1987). Primary productivity is N-limited for both $S$. patens and S. alterniflora (Mann 1977) and the species' border is maintained by a balance of competition and physical stress (Bertness \& Ellison 1987, Pennings \& Callaway 1992). In the absence of $S$. patens, $S$. alterniflora performs best in the high marsh, while stress restricts S. patens from the low marsh (Bertness \& Ellison 1987). When the $S$. patens zone is amended with N, S. alterniflora outcompetes $S$. patens (Emery et al. 2001). Under ambient N, $S$. patens is the stronger competitor, yet is less productive than $S$. alterniflora (Emery et al. 2001).

Over the past century, Phragmites australis (Poaceae) has expanded its role in the salt marsh plant community. Historically a minor component of salt marsh vegetation, the recent expansion is largely due to the introduction of an aggressive European genotype (Saltonstall 2002), now recognized as $P$. australis ssp. australis (Cav.) Trin Ex Steud. The native North American reed (now subspecies) P. australis ssp. americanus Saltonstall, P.M. Peterson and Soreng is less aggressive and does not form the dense monocultures typical of introduced $P$. australis (Saltonstall et al. 2004, League et al. 2006). Introduced $P$. australis is faster growing and more salt tolerant than the native (Vasquez et al. 2005), outcompetes the native in salt marshes, has higher tissue protein content and lower tissue C:N (Packett \& Chambers 2006), has higher photosynthetic rates (Mozdzer \& Zieman 2010) and better capitalizes on $\mathrm{N}$ increases than $P$. australis ssp. americanus (Saltonstall \& Stevenson 2007).

The salt marsh imposes a high $\mathrm{N}$ demand on vegetation, native or otherwise. Salinity stress elicits the production of nitrogenous osmoprotectants at the expense 
of growth (Colmer et al. 1996, Hester et al. 2001), requiring a high nitrogen use efficiency (NUE) to balance stress tolerance and growth (Stewart \& Rhodes 1978). Spartina alterniflora is more stress tolerant than S. patens (Maricle et al. 2007), but stress increases its N requirement (Bradley \& Morris 1992). To tolerate the low marsh environment, $S$. alterniflora has a higher Nuptake rate, NUE and biomass accumulation than S. patens (Drake et al. 2008). S. alterniflora is likewise more salt tolerant than introduced Phragmites australis (Vasquez et al. 2006); however, once established, P. australis can outcompete $S$. alterniflora under field salinities and has greater $\mathrm{N}$-uptake rates, tissue $\mathrm{N}$ concentration (Farnsworth \& Meyerson 2003), shoot biomass, root biomass (under controlled conditions: introduced $P$. australis $>$ native $P$. australis $>$ S. alterniflora), a higher affinity for $\mathrm{N}$ at low and high concentrations and more readily uses dissolved organic N (Mozdzer et al. 2010).

We compared Spartina patens and S. alterniflora and the 2 subspecies of Phragmites australis to investigate how the location of glutamine synthetase (GS) relates to growth in salt marsh plants. GS is the rate-limiting enzyme in amino acid biosynthesis (Lam et al. 1996, Kichey et al. 2006). As part of the GS-(GOGAT) cycle, GS assimilates inorganic $\mathrm{N}\left(\mathrm{NH}_{4}{ }^{+}\right)$by catalyzing the ammination of glutamate to glutamine (Miflin \& Lea 1977). Multiple isoforms of GS fall into 3 general categories: cytosolic $\mathrm{GS}_{\mathrm{I}}$, chloroplastic $\mathrm{GS}_{\mathrm{II}}$ and root-specific GS $\left(G_{R}\right)$ (Lam et al. 1996). Leaf GS is critical to amino acid biosynthesis both via the nitrate reduction/assimilatory pathway and in recovery of photorespiratory $\mathrm{NH}_{4}{ }^{+}$(Bauer et al. 1997, Cánovas et al. 2007). A recent molecular study has shown more diversity in structure and function of GS than previously recognized (Bernard et al. 2008).

Plants that preferentially increase leaf GS activity over root GS require less photosynthate for $\mathrm{N}$ assimilation (Schjoerring et al. 2002). Experimentally increasing leaf:root (L:R) GS activity confers a growth advantage, variously increasing photosynthetic rates (Fuentes et al. 2001), relative growth rate (Limami et al. 1999, Migge et al. 2000, Oliveira et al. 2002), stress tolerance (Hoshida et al. 2000) and tissue protein levels (Habash et al. 2001, Hirel et al. 2001, Oliveira et al. 2002, also see reviews by Andrews et al. 2004, Good et al. 2004). Transgenic plants with increased root GS activity decreased biomass production relative to controls (Limami et al. 1999, Harrison et al. 2003), indicating that the tissue-specific location of GS impacts fitness more than whole-plant GS activity.

Our first experiment compared GS partitioning in Spartina alterniflora and S. patens in the field. A second in situ experiment compared GS activity of Phragmites australis ssp. australis and P. australis ssp. amer- icanus. For our third experiment, we raised both Spartina spp. in a growth chamber with $3 \mathrm{~N}$ treatments to test the impacts of $\mathrm{N}$ source on GS activity. We hypothesized that the fast-growing, stress-tolerant $S$. alterniflora would have a higher L:R GS ratio than the congeneric $S$. patens in both field and controlled conditions. In Phragmites ssp., we hypothesized that introduced $P$. australis ssp. australis would have higher L:R GS activity than $P$. australis ssp. americanus.

\section{MATERIALS AND METHODS}

Spartina collection. Samples of S. alterniflora and $S$. patens were collected from the Little River Marsh on the Wells National Estuarine Research Reserve (Wells, $\mathrm{ME}, 43^{\circ} 20^{\prime} 12.21^{\prime} \mathrm{N}, 70^{\circ} 32^{\prime} 24.25^{\prime} \mathrm{W}$ ). We sampled on 3 occasions during the growing season of 2005: July $(\mathrm{n}=10)$, August $(\mathrm{n}=10)$ and October $(\mathrm{n}=5)$ prior to senescence. Samples were randomly selected along a transect bordering the $S$. patens and $S$. alterniflora zones. Leaf samples consisted of all above-ground growth for each plant; rhizomes were not tested for GS activity. Plant material was rinsed in cool freshwater, separated into root and shoot and placed in liquid nitrogen $\left(\mathrm{LN}_{2}\right)$. Soil water from the root sample was filtered onto a $\mathrm{NaCl}$ refractometer to determine pore water salinity. Soil temperatures were recorded using an analog soil thermometer.

Cation exchange resin bags ( $10 \mathrm{~g}$ resin) were used to determine plant-available $\mathrm{NH}_{4}{ }^{+}$in the Spartina alterniflora and $S$. patens zones $(\mathrm{n}=10)$ for the growing season of July to October (modified from Binkley \& Matson 1983). In autumn 2005, resins were air-dried, cleaned of roots and silt, and eluted in $1 \mathrm{~N} \mathrm{KCl}$. Following $18 \mathrm{~h}$ incubation at ambient temperature, vacuumfiltered (Whatman \#1) elutions were sent to the University of Maine Soil Analysis Lab to determine $\mathrm{NH}_{4}{ }^{+}$ concentrations.

Phragmites collection. We harvested the 3 uppermost fully developed leaves and viable root tissue from each subspecies $(\mathrm{n}=10)$ from the Libby River Marsh

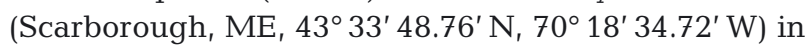
late August 2004. Subspecies were distinguished using morphological characteristics and type specimens were sent to the Phragmites Diagnostic Service (www.invasiveplants.net) to corroborate our identifications. Native and introduced samples were chosen haphazardly, washed in cool freshwater and immersed in $\mathrm{LN}_{2}$. Environmental characteristics were not recorded for $P$. australis.

Growth chamber. For our growth chamber experiment, seeds of Spartina alterniflora and $S$. patens were cold-stratified at $4{ }^{\circ} \mathrm{C}$ in $40 \% \mathrm{NaCl}$ solution for $4 \mathrm{wk}$ (modified from McIninch \& Garbisch 2004) and then 
planted in a medium of $50 \%$ sand and $50 \%(\mathrm{v} / \mathrm{v}) \mathrm{com}-$ mercial potting mix. Attempts to germinate seeds on sand alone were unsuccessful. Seedlings were transplanted to individual cups and maintained under a $16 \mathrm{~h}$ light:8 h dark cycle of $900 \mu \mathrm{E} \mathrm{m} \mathrm{m}^{-2} \mathrm{~s}^{-1}$ at $24^{\circ} \mathrm{C}$ for 5 mo. Three $\mathrm{N}$ treatments consisted of either $10 \mathrm{mM}$ $\mathrm{NH}_{4}{ }^{+}$(from $\left[\mathrm{NH}_{4}{ }^{+}\right] 2 \mathrm{SO}_{4}$ ), $10 \mathrm{mM} \mathrm{NO}_{3}{ }^{-}$(from $\mathrm{KNO}_{3}$ ) or $5 \mathrm{mM} \mathrm{NH}_{4}{ }^{+}$and $5 \mathrm{mM} \mathrm{NO}_{3}{ }^{-}$, in a modified nutrient solution. Nutrient concentrations were chosen to minimize $\mathrm{N}$ limitation. Non-draining nursery trays (9 plants of each species per tray) prevented crosscontamination between nutrient treatments ( 2 trays per treatment). The trays were arranged randomly and the plants sat in 2 to $4 \mathrm{~cm}$ of freshwater throughout the experiment, to avoid differential responses to a given salinity level. Water (500 ml tray $\left.{ }^{-1} 0.5 \mathrm{wk}^{-1}\right)$ and nutrient treatments $\left(25 \mathrm{ml}\right.$ plant $^{-1} \mathrm{wk}^{-1}$ ) were applied from top and bottom, respectively, providing $2.5 \mathrm{mg} \mathrm{N} \mathrm{m}^{-2}$ $\mathrm{d}^{-1}$. Mature plants were harvested in the same manner as field samples. Six samples of each species per treatment were used to determine GS and an additional 6 were dried to determine biomass.

Enzyme analysis. All samples were stored at $-70^{\circ} \mathrm{C}$ until processed. Leaf samples were washed in ice water $\left(<4^{\circ} \mathrm{C}\right)$ and homogenized in liquid nitrogen using all leaf material for each plant. Viable root tissue was homogenized by the same method as leaf tissue. To extract enzymes, field samples of both Spartina spp. and Phragmites australis ssp. were ground in a chilled imidazole extraction buffer of $\mathrm{pH} 7.5$ (modified from Knight \& Langston-Unkefer 1988) and then clarified by centrifugation. Chamber-grown plants were treated as field samples, with one exception: enzymes were extracted in the buffer described in Long \& Oaks (1990), which is compatible with assays for nitrate reductase and the GS assay used here (T. J. Knight unpubl. data). Attempts to determine nitrate reductase levels were unsuccessful on frozen tissue and were omitted from analysis (see discussion in Mendelssohn 1979). GS activity in leaf and root samples was determined by the glutamine synthetase transferase assay (Shapiro \& Stadtman 1970). Each sample was assayed in triplicate and the GS activity was determined as the optical density (OD) at $540 \mathrm{~nm}$.

Each sample's OD readings were averaged and standardized to GS activity (reaction product: $\mu \mathrm{M}$ gammaglutamyl-hydroxamate $\mathrm{g}^{-1} \mathrm{~min}^{-1}$ ). An L:R GS activity ratio was calculated from the leaf and root activities for each individual plant. Species differences were analyzed by 1- or 2-way ANOVA (see Table 2) and logtransformed as necessary (Sokal \& Rohlf 2003). Ratio data were compared by Wilcoxon's signed rank test, which is more suited to ratios than ANOVA (Legendre \& Legendre 2004). All statistical analyses were conducted in $\mathrm{JMP}^{\circledR}$ (SAS Institute, www.sas.com).

\section{RESULTS AND DISCUSSION}

Research on agricultural species connects elevated L:R GS activity to fitness advantages and our results showed similar patterns in salt marsh grasses. Our data support the hypothesis that the faster growing and more stress-tolerant species of Spartina would have significantly higher L:R GS activity than the slower growing congener across all field sampling events and under certain nutrient conditions in growth chamber treatments. While we are not able to accept the hypothesis that introduced Phragmites australis would have higher L:R GS activity than the native subspecies, both subspecies had higher values than Spartina spp.

In field-collected plants, L:R GS activity varied between sampling dates in both species (see Habash et al. 2001); however, Spartina alterniflora was consistently higher than $S$. patens (July: $p=0.002$; August: $\mathrm{p}=0.0006$; October: $\mathrm{p}=0.02$; species $\times$ month: $\mathrm{p}=$ 0.017; Fig. 1). Root GS activity was significantly different between species for all sampling events (July: $p$ < 0.0001; August: $\mathrm{p}<0.0001$; October: $\mathrm{p}=0.006$; Fig. 1). Leaf GS activity was only substantially different in the August samples ( $p=0.0517$; Fig. 1).
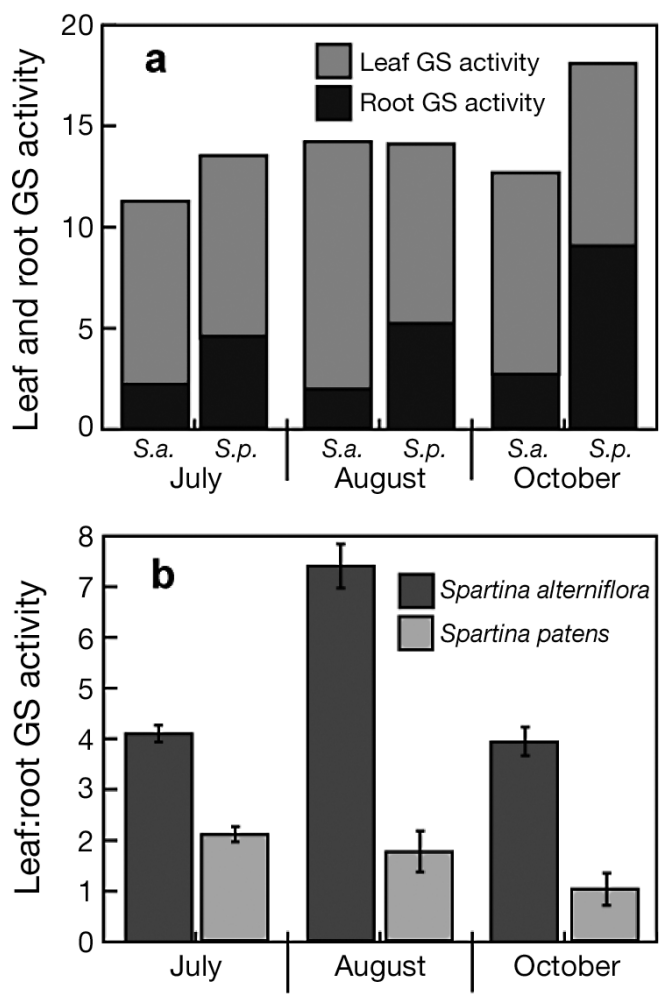

Fig. 1. Spartina alterniflora and S. patens. Glutamine synthetase (GS) activity in field-collected $S$. alterniflora (S.a.) and $S$. patens (S.p.). Results are grouped by sampling event. (a) Mean leaf and root GS activity ( $\mu \mathrm{M}$ gamma-glutamylhydroxamate $\mathrm{g}^{-1} \mathrm{~min}^{-1}$ ). (b) Mean leaf:root GS activity ( $\pm 1 \mathrm{SE}$ ) 
Soil ammonium, salinity and temperature in Spartina patens and $S$. alterniflora zones were not significantly different at any sampling period (Table 1). Our samples were chosen from monocultures close to the boundary of $S$. alterniflora and $S$. patens, where the environmental conditions may not vary as dramatically as deeper within the vegetation zones.

Chamber-grown Spartina spp. had significantly different L:R GS activity in the nitrate $(p=0.02)$ and control (which received both $\mathrm{N}$ sources; $\mathrm{p}=0.005$ ) treatments. The 2 Spartina spp. had similar L:R GS activity when grown on $\mathrm{NH}_{4}{ }^{+}$, but this may be related to chlorosis observed in our ammonium-treated plants, making it difficult to differentiate between treatment and injury. Similar to our field experiment, species' leaf GS activities were not significantly different in any treatment, while root GS activity differed between species in the nitrate (marginally not significant, $\mathrm{p}=$ 0.078 ) and control $(p=0.0003)$ treatments (Fig. 2). Biomass varied with treatment $(p=0.036)$, but not by species (Table 2), indicating that the 2 species responded similarly to $\mathrm{N}$ source, including decreased biomass in the nitrate treatment (Fig. 2).

Phragmites australis subspecies were not significantly different in leaf, root or L:R GS activity (Fig. 3). Leaf GS activities in both $P$. australis ssp. were comparable to August leaf GS in $S$. alterniflora (native: 13.09 \pm 0.65 ; introduced: $12.76 \pm 0.56 ; \mathrm{p}=0.729$ ). Root GS activity was minimal in both subspecies (native: $1.12 \pm$ 0.14 ; introduced: $0.97 \pm 0.11 ; \mathrm{p}=0.397$ ), indicating that

Fig. 2. Spartina alterniflora and S. patens. Glutamine synthetase (GS) activity and biomass production in chambergrown Spartina grasses. S. alterniflora and $S$. patens samples received one of $3 \mathrm{~N}$ treatments: $\mathrm{NH}_{4}{ }^{+}, \mathrm{NO}_{3}{ }^{-}$, or $\mathrm{NH}_{4}{ }^{+} / \mathrm{NO}_{3}{ }^{-}$ combined. (a) Mean leaf and root GS activity ( $\mu \mathrm{M}$ gammaglutamyl-hydroxamate $\mathrm{g}^{-1} \mathrm{~min}^{-1}$ ). (b) Mean leaf:root (L:R) GS activity ( $\pm 1 \mathrm{SE})$. (c) Biomass production
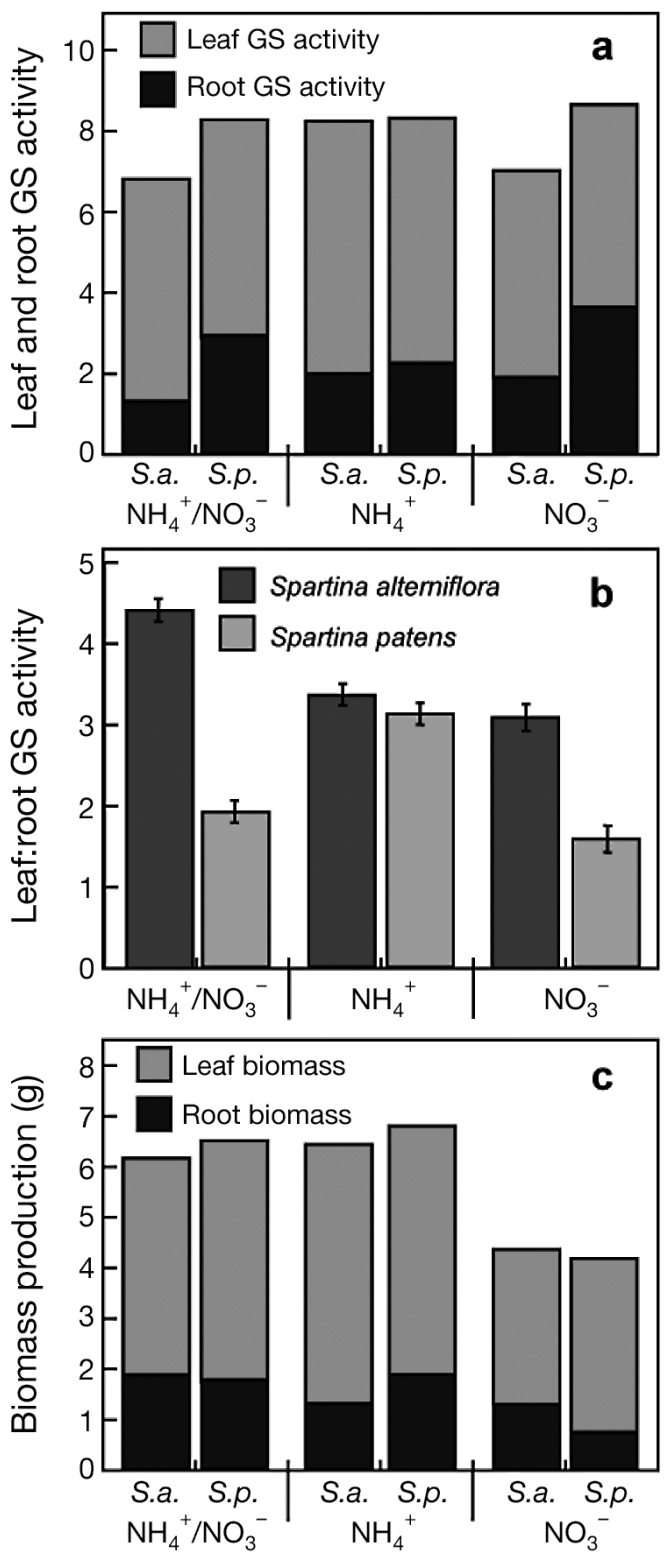

Table 1. Mean in situ soil temperature $\left({ }^{\circ} \mathrm{C}\right)$ and salinity $(\%)$ recorded for field-collected Spartina grasses $( \pm 1$ SE). Both temperature and salinity were measured at the same depth as the root sample. Soil ammonium is a season-long (July-October) measure, expressed as $\mathrm{mg} \mathrm{NH}_{4}^{+}(10 \mathrm{~g} \text { resin })^{-1}$

\begin{tabular}{|c|c|c|c|c|c|}
\hline Month & S. patens & S. alterniflora & df & $F$ & $\mathrm{p}$ \\
\hline \multicolumn{6}{|l|}{ Soil salinity } \\
\hline July & $28.00 \pm 0.516$ & $29.00 \pm 0.516$ & 9 & 1.875 & 0.1877 \\
\hline August & $29.90 \pm 0.348$ & $30.10 \pm 0.348$ & 9 & 0.1651 & 0.6893 \\
\hline October & $13.80 \pm 2.142$ & $14.80 \pm 2.142$ & 4 & 0.1098 & 0.7498 \\
\hline \multicolumn{6}{|c|}{ Soil temperature } \\
\hline July & $17.10 \pm 0.272$ & $16.60 \pm 0.272$ & 9 & 1.6917 & 0.2098 \\
\hline August & $15.00 \pm 0.189$ & $15.40 \pm 0.189$ & 9 & 2.25 & 0.151 \\
\hline October & $8.00 \pm 0.424$ & $7.40 \pm 0.424$ & 4 & 1 & 0.3466 \\
\hline \multicolumn{6}{|c|}{ Soil ammonium } \\
\hline July-October & $1.59 \pm 0.21$ & $1.31 \pm 0.21$ & 9 & 0.8232 & 0.376 \\
\hline
\end{tabular}


Table 2. Results of 2-way ANOVAs on leaf and root glutamine synthetase (GS) activities ( $\mu$ M gamma-glutamyl-hydroxamate g ${ }^{-1}$ $\min ^{-1}$ ), leaf:root (L:R) GS activity ratios and biomass production (g dry weight) in Spartina grasses from field and growth chamber studies. Values in bold are significant

\begin{tabular}{|c|c|c|c|c|c|}
\hline Source & Variable & Effect & df & $F$ & $\mathrm{p}$ \\
\hline Field & L:R GS & $\begin{array}{l}\text { Species } \\
\text { Month } \\
\text { Species } \times \text { Month } \\
\text { Species } \\
\text { Month } \\
\text { Species } \times \text { Month } \\
\text { Species } \\
\text { Month } \\
\text { Species } \times \text { Month }\end{array}$ & $\begin{array}{l}1 \\
2 \\
2 \\
1 \\
2 \\
2 \\
1 \\
2 \\
2\end{array}$ & $\begin{array}{r}1.83 \\
1.98 \\
2.23 \\
0.31 \\
10.46 \\
38.49 \\
36.71 \\
4.65 \\
4.48\end{array}$ & $\begin{array}{r}0.184 \\
0.151 \\
0.121 \\
0.584 \\
\mathbf{0 . 0 0 2} \\
<\mathbf{0 . 0 0 0 1} \\
<\mathbf{0 . 0 0 0 1} \\
\mathbf{0 . 0 1 5} \\
\mathbf{0 . 0 1 7}\end{array}$ \\
\hline Growth chamber & Leaf GS & $\begin{array}{l}\text { Species } \\
\text { Treatment } \\
\text { Species } \times \text { Treatment } \\
\text { Species } \\
\text { Treatment } \\
\text { Species } \times \text { Treatment } \\
\text { Species } \\
\text { Treatment } \\
\text { Species } \times \text { Treatment } \\
\text { Species } \\
\text { Treatment } \\
\text { Species } \times \text { Treatment }\end{array}$ & $\begin{array}{l}1 \\
2 \\
2 \\
1 \\
2 \\
2 \\
1 \\
2 \\
2 \\
1 \\
2 \\
2\end{array}$ & $\begin{array}{c}0.05 \\
1.47 \\
0.001 \\
12.27 \\
1.56 \\
1.82 \\
11.94 \\
1.96 \\
2.55 \\
0.004 \\
3.77 \\
0.08\end{array}$ & $\begin{array}{l}0.82 \\
0.247 \\
0.999 \\
\mathbf{0 . 0 0 1 5} \\
0.227 \\
0.179 \\
\mathbf{0 . 0 0 1 7} \\
0.159 \\
0.095 \\
0.949 \\
\mathbf{0 . 0 3 5} \\
0.919\end{array}$ \\
\hline
\end{tabular}
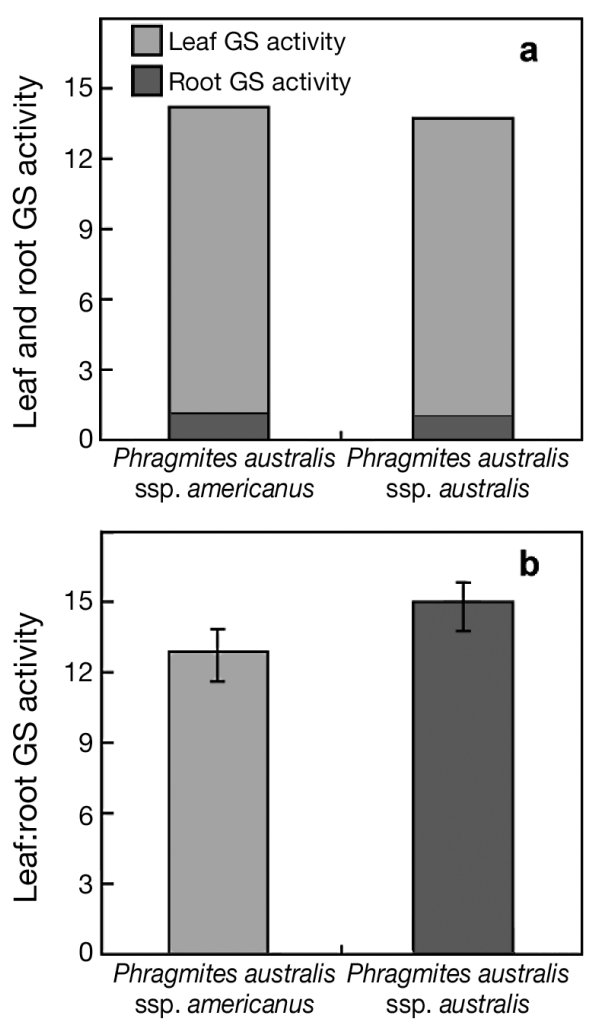

Fig. 3. Phragmites australis ssp. Glutamine synthetase (GS) activity in field-collected native ( $P$. australis ssp. americanus) and introduced ( $P$. australis ssp. australis) $P$. australis subspecies. (a) Mean leaf and root GS activity ( $\mu \mathrm{M}$ gammaglutamyl-hydroxamate $\mathrm{g}^{-1} \mathrm{~min}^{-1}$ ). (b) Mean leaf:root GS activity $( \pm 1 \mathrm{SE})$ this species conducts nearly all $\mathrm{N}$ assimilation in photosynthetic tissue.

The magnitude of GS partitioning in Phragmites australis subspecies exceeds any terrestrial plant identified in the literature, excluding transgenic or hybrid plants. Previous studies have found L:R GS activity ratios as high as 12:1 in transgenic tobacco (Nicotiana spp.) which overexpresses genes for leaf GS (T. J. Knight unpubl. data), and 21:1 in hybrid strawberries (Fragaria spp.; Claussen \& Lenz 1999). Work on submerged marine angiosperms Zostera noltii and Cymodocea nodosa reported L:R GS activities more than 10 -fold the values recorded in terrestrial plants, which corresponded to differences in their growth rates (Kraemer \& Mazzella 1999), demonstrating that the fitness advantages associated with high L:R GS activity hold true across a broad range of taxa.

In the absence of a direct comparison, our observed L:R GS activities coincide with reports of fitness and growth within and between our study genera. Both subspecies of Phragmites australis assimilate organic $\mathrm{N}$ faster than Spartina alterniflora (Mozdzer et al. 2010). Introduced $P$. australis has faster growth rates than S. patens (Windham 2001) and S. alterniflora (Farnsworth \& Meyerson 2003), and S. alterniflora has higher NUE, relative growth rate and biomass production than S. patens (Drake et al. 2008).

Prior work on GS in salt marsh plants found that GS activity changed with environmental cues. Stewart \& Rhodes (1978) tested activity of N-assimilation enzymes in salt marsh species, proposing that production of 
N-based osmolytes requires a high NUE. As salinities increased, leaf GS increased and root GS decreased in all species tested. In a later study, Ahmad et al. (1982) found that $\mathrm{GS}_{\mathrm{II}}$ and $\mathrm{GS}_{\mathrm{R}}$ in the halophyte Triglochin maritima were more sensitive to salinity than $\mathrm{GS}_{\mathrm{I}}$, and salinity decreases root GS activity. Following increased leaf GS activity, glutamine levels increased, followed by proline, glycine betaine and other compatible solutes. Increases in GS activity may be a direct response to physiological stress, either for osmolyte production or stress recovery (Stewart et al. 1977). Salt-sensitive root GS may offer a fitness advantage to halophytes. Our observation that root GS activities changed with time and $\mathrm{N}$ source, while leaf GS activity remained constant, suggests that multiple cues (temporal or environmental) affect root GS, while leaf GS is less sensitive.

Many plants (particularly C4 plants) require a low level of salinity in order to reach their photosynthetic maximum. In Spartina alterniflora, C:N decreases and tissue $\mathrm{N}$ increases with rising salinity (Bradley \& Morris 1992), which also corresponds with elevated proline and glycine betaine levels (Naidoo et al. 1992) and an elevated growth rate at moderate salinities (Wang et al. 2006). Spartina spp. reach their optimum growth rate and stomatal conductance at salinities between 10 and 20\%o (Maricle et al. 2007). Experimental results have shown that $\mathrm{N}$ uptake and relative growth rate increase in Phragmites australis with increasing salinities (Chambers et al. 1998, Vasquez et al. 2005). Native $P$. australis increases $\mathrm{N}$ uptake with up to $20 \%$ increased salinity (Mozdzer et al. 2010). Hartzendorf \& Rolletschek (2001) observed an increase in proline and glutamine concentrations and a decrease in asparagines and glutamate in $P$. australis leaf and rhizome tissue with increasing salinity. Similar changes in photosynthetic rate, tissue $\mathrm{N}, \mathrm{N}$ uptake, growth rate and amino acid concentrations have been observed in plants with elevated L:R GS activity (reviewed in Andrews et al. 2004, Good et al. 2004). Inducible increases in L:R GS activity may impact the way plants avoid (osmolyte production), tolerate (salinity-resistant physiology) or recover from (increased amino acid biosynthesis) physical stress.

In conclusion, the faster growing and more stresstolerant Spartina species had a higher L:R GS activity rate than its congener in both field and controlledgrowth studies. Our observations coincide with reports of growth, stress tolerance and competition in these 2 species. We did not find higher L:R GS activity in the competitively dominant Phragmites australis ssp. australis than the native $P$. australis ssp. americanus; however, our observations may be more important than the initial question. The magnitude of GS partitioning observed in $P$. australis ssp. was among the highest reported and may contribute to the success of this cosmopolitan species known for high relative growth rate and NUE. The relationship between our results and observations in the literature warrant further research into both the mechanism and ecology of L:R GS partitioning.

Acknowledgements. The authors thank B. Blossey, A. Dayton, M. Dionne, P. Hazelton, L. Jones, S. Lindsay, B. Logan, J. Roths, L. Vickers, J. Wheeler, T. Willis and K. Wilson for their ideas, sweat and support. This study was partially supported by a Maine ScienceCorps Teaching Fellowship (NSF grant no. DGE-0440560 to E.H.), a USM Biology Teaching Assistantship to E.H. and the USM Biol. Dept. Grad. Res. Fund. Fieldwork at Rachel Carson National Wildlife Refuge and Wells National Estuarine Research Reserve was conducted under permit no. 53553-2005-023. To the authors' knowledge, the experiments presented here comply with the current laws of the country in which they were performed and all material was collected under the requisite permits for each site.

\section{LITERATURE CITED}

Ahmad I, Larher F, Mann AF, McNally SF, Stewart GR (1982) Nitrogen metabolism in halophytes. IV. Characteristics of glutamine synthetase from Triglochin maritima L. New Phytol 91:585-595

Andrews M, Lea PJ, Raven JA, Lindsey K (2004) Can genetic manipulation of plant nitrogen assimilation enzymes result in increased crop yield and greater N-use efficiency? An assessment. Ann Appl Biol 145:25-40

Bauer D, Biehler K, Fock H, Carrayol E, Hirel B, Migge A, Becker TW (1997) A role for cytosolic glutamine synthetase in the remobilization of leaf nitrogen during water stress in tomato. Physiol Plant 99:241-248

> Bernard SM, Møller ALB, Dionisio G, Kichey T and others (2008) Gene expression, cellular localisation and function of glutamine synthetase isozymes in wheat (Triticum aestivum). Plant Mol Biol 67:89-105

Bertness MD, Ellison AM (1987) Determinants of pattern in a New England salt marsh plant community. Ecol Monogr 57:129-147

Binkley D, Matson M (1983) Ion exchange resin bag method for assessing forest soil nitrogen availability. Soil Sci Soc Am J 47:1050-1052

Bradley PM, Morris JT (1992) Effects of salinity on the critical nitrogen concentration of Spartina alterniflora Loisel. Aquat Bot 43:149-161

Cánovas FM, Avila C, Cantón FR, Canas RA, de la Torre F (2007) Ammonium assimilation and amino acid metabolism in conifers. J Exp Bot 58:2307-2318

Chambers RM, Mozdzer TJ, Ambrose JC (1998) Effects of salinity and sulfide on the distribution of Phragmites australis and Spartina alterniflora in a tidal salt marsh. Aquat Bot 62:161-169

Claussen W, Lenz F (1999) Effect of ammonium or nitrate nutrition on net photosynthesis, growth and activity of the enzymes nitrate reductase and glutamine synthetase in blueberry, raspberry and strawberry. Plant Soil 208: 95-102

Colmer TD, Fan TWM, Lauchli A, Higashi RM (1996) Interactive effects of salinity, nitrogen and sulphur on the organic solutes in Spartina alterniflora leaf blades. J Exp Bot 47: 369-375 
Drake DC, Peterson BJ, Deegan LA, Harris LA, Miller EE, Warren RS (2008) Plant nitrogen dynamics in fertilized and natural New England salt marshes: a paired ${ }^{15} \mathrm{~N}$ tracer study. Mar Ecol Prog Ser 354:35-46

Emery NC, Ewanchuk PJ, Bertness MD (2001) Competition and salt-marsh plant zonation: stress tolerators may be dominant competitors. Ecology 82:2471-2485

Farnsworth EJ, Meyerson LA (2003) Comparative ecophysiology of four wetland plant species along a continuum of invasiveness. Wetlands 23:750-762

Fuentes SI, Allen DJ, Ortiz-Lopez A, Hernandez G (2001) Over-expression of cytosolic glutamine synthetase increases photosynthesis and growth at low nitrogen concentrations. J Exp Bot 52:1071-1081

Good AG, Shrawat AK, Muench DG (2004) Can less yield more? Is reducing nutrient input into the environment compatible with maintaining crop production? Trends Plant Sci 9:597-605

Habash DZ, Rong HL, Wallsgrove RM, Leigh R (2001) The role of cytosolic glutamine synthetase in wheat. Ann Appl Biol 138:83-89

Harrison J, Pou de Crescenzo MA, Sene O, Hirel B (2003) Does lowering glutamine synthetase activity in nodules modify nitrogen metabolism and growth of Lotus japponicus? Plant Physiol 133:253-262

Hartzendorf T, Rolletschek H (2001) Effects of NaCl-salinity on amino acid and carbohydrate contents of Phragmites australis. Aquat Bot 69:195-208

Hester MW, Mendelssohn IA, McKee KL (2001) Species and population variation to salinity stress in Panicum hemitomon, Spartina patens and Spartina alterniflora: morphological and physiological constraints. Environ Exp Bot 46:277-297

Hirel B, Bertin P, Quillere I, Bourdoncle W and others (2001) Towards a better understanding of the genetic and physiological basis for nitrogen use efficiency in maize. Plant Physiol 125:1258-1270

> Hoshida H, Tanaka Y, Hibino T, Hayashi Y, Tanaka A, Takabe T, Takabe T (2000) Enhanced tolerance to salt stress in transgenic rice that overexpresses chloroplast glutamine synthetase. Plant Mol Biol 43:103-111

Kichey T, Heumez E, Pocholle D, Pageau K and others (2006) Combined agronomic and physiological aspects of nitrogen management in wheat highlight a central role for glutamine synthetase. New Phytol 169:265-278

Knight TJ, Langston-Unkefer PJ (1988) Enhancement of symbiotic dinitrogen fixation by a toxin-releasing plant pathogen. Science 241:951-954

Kraemer GP, Mazzella L (1999) Nitrogen acquisition, storage, and use by the co-occurring Mediterranean seagrasses Cymodocea nodosa and Zostera noltii. Mar Ecol Prog Ser 183:95-103

> Lam HM, Coschigano KT, Oliveira IC, Melo-Oliveira R, Coruzzi GM (1996) The molecular-genetics of nitrogen assimilation into amino acids in higher plants. Annu Rev Plant Physiol Mol Biol 47:569-593

> League MT, Colbert EP, Seliskar DM, Gallagher JL (2006) Rhizome growth dynamics of native and exotic haplotypes of Phragmites australis (common reed). Estuaries 29: 269-276

Legendre P, Legendre L (2004) Numerical ecology, 2nd English edn. Elsevier, Amsterdam

> Limami A, Phillipson B, Ameziane R, Pernollet N and others (1999) Does root glutamine synthetase control plant biomass production in Lotus japonicus L.? Planta 209: 495-502

> Long DM, Oaks A (1990) Stabilization of nitrate reductase in maize roots by chemostatin. Plant Physiol 93:846-850
Mann KH (1977) Nitrogen limitations on the productivity of Spartina marshes, Laminaria kelp beds and higher trophic levels. In: Jefferies RL, Davy AJ (eds) Ecological processes in coastal environments. Blackwell Scientific Publications, Oxford, p 363-370

Maricle BR, Cobos DR, Campbell CS (2007) Biophysical and morphological leaf adaptations to drought and salinity in salt marsh grasses. Environ Exp Bot 60:458-467

McIninch SH, Garbisch EW (2004) Propagation of wetland plants: herbaceous plants, shrubs, and trees. Environmental Concern, St. Michaels, MD

> Mendelssohn IA (1979) Nitrogen-metabolism in the height forms of Spartina alterniflora in North Carolina. Ecology 60:574-584

Miflin BJ, Lea PJ (1977) Amino-acid metabolism. Annu Rev Plant Physiol Mol Biol 28:299-329

Migge A, Carrayol E, Hirel B, Becker TW (2000) Leaf-specific overexpression of plastidic glutamine synthetase stimulates the growth of transgenic tobacco seedlings. Planta 210:252-260

> Mozdzer TJ, Zieman JC (2010) Ecophysiological differences between genetic lineages facilitate the invasion of nonnative Phragmites australis in North American Atlantic coast wetlands. J Ecol 98:451-458

> Mozdzer TJ, Zieman JC, McGlathery KJ (2010) Nitrogen uptake by native and invasive temperate coastal macrophytes: importance of dissolved organic nitrogen. Estuar Coasts 33:784-797

> Naidoo G, McKee KL, Mendelssohn IA (1992) Anatomical and metabolic responses to waterlogging and salinity in Spartina alterniflora and $S$. patens (Poaceae). Am J Bot 79:765-770

Oliveira IC, Brears T, Knight TJ, Clark A, Coruzzi GM (2002) Overexpression of cytosolic glutamine synthetase. Relation to nitrogen, light and photorespiration. Plant Physiol 129:1170-1180

Packett CR, Chambers RM (2006) Distribution and nutrient status of haplotypes of the marsh grass Phragmites australis along the Rappahannock River in Virginia. Estuaries 29:1222-1225

> Pennings SC, Callaway RM (1992) Salt-marsh plant zonation: the relative importance of competition and physical factors. Ecology 73:681-690

Saltonstall K (2002) Cryptic invasion by a non-native genotype of the common reed, Phragmites australis, into North America. Proc Natl Acad Sci USA 99:2445-2449

Saltonstall K, Stevenson JC (2007) The effect of nutrients on seedling growth of native and introduced Phragmites australis. Aquat Bot 86:331-336

Saltonstall K, Peterson PM, Soreng RJ (2004) Recognition of Phragmites australis subsp. americanus (Poaceae: Arundinoideae) in North America: evidence from morphological and genetic analyses. SIDA Contrib Bot 21:683-692

Schjoerring JK, Husted S, Mack G, Mattsson M (2002) The regulation of ammonium translocation in plants. J Exp Bot 53:883-890

Shapiro BM, Stadtman ER (1970) Glutamine synthetase (Escherichia coli). In: Tabor H, Tabor CW (eds) Methods in enzymology, Vol 17A: metabolism of amino acids and amines. Academic Press, New York, NY, p 910-921

Sokal RR, Rohlf FJ (2003) Biometry: the principles and practice of statistics in biological research. W. H. Freeman, New York, NY

> Stewart GR, Rhodes D (1978) Nitrogen metabolism in halophytes. III. Enzymes of ammonia assimilation. New Phytol 80:307-316

Stewart GR, Larher F, Ahmad I, Lee IA (1977) Nitrogen 
metabolism and salt-tolerance in higher plant halophytes. In: Jefferies RL, Davy AJ (eds) Ecological processes in coastal environments. Blackwell Scientific Publications, Oxford, p 211-227

Vasquez EA, Glenn EP, Brown JJ, Guntenspergen GR, Nelson SG (2005) Salt tolerance underlies the cryptic invasion of North American salt marshes by an introduced haplotype of the common reed Phragmites australis (Poaceae). Mar Ecol Prog Ser 298:1-8

Vasquez EA, Glenn EP, Guntenspergen GR, Brown JJ, Nelson SG (2006) Salt tolerance and osmotic adjustment of

Editorial responsibility: Hans Heinrich Janssen, Oldendorf/Luhe, Germany
Spartina alterniflora (Poaceae) and the invasive M haplotype of Phragmites australis (Poaceae) along a salinity gradient. Am J Bot 93:1784-1790

> Wang Q, Wang CH, Zhao B, Ma ZJ, Luo YQ, Chen JK, Li B (2006) Effects of growing conditions on the growth of and interactions between salt marsh plants: implications for the invasibility of habitats. Biol Invasions 8:1547-1560

Windham L (2001) Comparison of biomass production and decomposition between Phragmites australis (common reed) and Spartina patens (salt hay grass) in brackish tidal marshes of New Jersey, USA. Wetlands 21:179-188

Submitted: July 20, 2009; Accepted: June 10, 2010

Proofs received from author(s): August 18, 2010 